\title{
HPV E6/E7 mRNA transcripts as predictors of high-grade epithelial
} cervix dysplasia J Möckel*1, A Clad $^{2}$, A-S Endres ${ }^{3}$ and V Schneider ${ }^{4}$

\author{
Address: ${ }^{1}$ Institut für Pathologie, Klinikum Lahr, Germany, ${ }^{2}$ Universitäts-Frauenklinik Freiburg, Germany, ${ }^{3}$ Institut für Virologie, Charite \\ Universitätsmedizin, Berlin, Germany and ${ }^{4}$ Pathologisches Institut Dr. Schneider, Freiburg, Germany \\ * Corresponding author
}

from 35te Tagung der Pathologen am Oberrhein/35th Meeting of Pathologists of the Upper Rhine Region (PATOR)

The Institute of Pathology, University Hospital Freiburg, Germany. I July 2006

Published: I4 March 2007

Diagnostic Pathology 2007, 2(Suppl I):SI doi:I0.II86/I746-I596-2-SI-SI

(c) 2007 Möckel et al; licensee BioMed Central Ltd.

\begin{abstract}
Aims
Detection of E6 and E7 mRNA transcripts has been shown to be of higher prognostic value for the evaluation of the precursor lesions of cervical carcinoma than the detection of HPV DNA in a number of pilot studies [1-3]. In particular in low grade lesions, HPV DNA testing has poor discriminating power as to the progression of CIN, thus leading to considerable overtreatment with ensuing costs to the health care system. We tested an E6, E7 mRNA detection system in a multicenter study in Germany for its usefulness in clinical practice.
\end{abstract}

\section{Methods}

We recruited 334 high-risk ambulatory patients in five clinics with cervical lesions ranging from low-grade intraepithelial lesions to invasive cervical carcinoma. Colposcopy, conventional cytology, HPV-DNA testing (Hybrid Capture II, Digene Corp.), HPV-mRNA-testing (PreTect HPV-Proofer, NorChips AS, Norway) and histologic sampling (biopsies and conisations) were performed.

\section{Results}

There were 140 patients WNL, 64 patients with CIN I/II, 98 patients with CIN III and 32 patients with invasive carcinoma. HPV-DNA testing was positive in $24 \%, 78 \%$, $92 \%$ and $97 \%$, respectively. E6/E7 mRNA positivity rate were $8 \%, 41 \%, 64 \%$ and $94 \%$.

\section{Conclusion}

The mRNA-based test showed a higher prognostic value than DNA-based testing in a high-risk population of several dysplasia clinics in Germany. Thus, gene expression profiling of the viral oncogenes E6 and E7 showed superi- ority to DNA testing in triaging patients with cervical carcinoma precursors.

\section{References}

I. Kraus I, Molden T, Erno LE, Skomedal H, Karlsen F, Hagmar B: Human papillomavirus oncogenic expression in the dysplastic portio; an investigation of biopsies from 190 cervical cones. Br J Cancer 2004, 90: I407-1413.

2. Cuschieri KS, Whitley MJ, Cubie HA: Human papillomavirus type specific DNA and RNA persistence-implications for cervical disease progression and monitoring. J Med Virol 2004, 73:65-70.

3. Lie AK, Risberg B, Sandstad B, Delabie J, Rimala R, Hagen B, Onsrud $M$, Thoresen S: DNA versus RNA based methods for HPV testing in Norway. Evaluation of Hybrid Capture II and PreTect HPV-Proofer, a validation study. 2 Ist International Papillomavirus Conference: February 20 - 26, 2004; Mexico City . Abstract 